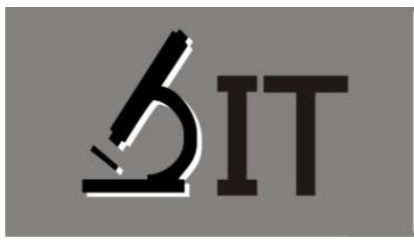

p-ISSN : 2597-8977

e-ISSN : $2597-8985$

Hj Sitti Hadijah*)

SMP Negeri 3 Palopo

*) Correspondence Author: Kasmi2009indi@gmail.com
JIT 4 (2) (2021) 63-73

JURNAL IPA TERPADU

http://ojs.unm.ac.id/index.php/ipaterpadu

\section{PENERAPAN DISCOVERY LEARNING UNTUK MENINGKATKAN HASIL BELAJAR DAN PENANAMAN KARAKTER PESERTA DIDIK KELAS IXA SMP NEGERI 3 PALOPO}

Abstrak: Penelitian ini bertujuan untuk meningkatkan hasil belajar dan penanaman karakter peserta didik kelas IXA SMP Negeri 3 Palopo yang dibelajarkan dengan penerapan model Discovery learning berbasis pendekatan saintifik materi sistem reproduksi. Penelitian ini merupakan penelitian tindakan kelas yang dilaksanakan dalam dua siklus setiap siklus terdiri dari empat tahapan yaitu perencanaan, pelaksanaan, pengamatan, dan refleksi. Subjek penelitian yaitu satu orang guru dan seluruh peserta didik kelas IXA SMP Negeri 3 Palopo Sebanyak 31 orang. Pengumpulan data menggunakan teknik tes. Analisis data menggunakan teknik deskriptif. Aktifitas peserta didik terdiri dari dua kategori, untuk kategori positif mengalami peningkatan dari siklus I kesiklus II untuk beberapa aspek sampai $100 \%$ dan kategori negatif mengalami penurunan sampai $0 \%$ untuk beberapa aspek. Hasil belajar pada siklus II mengalami peningkatan peningkatan menjadi 31 orang siswa (100\%) yang hasil belajarnya tuntas. Hasil penelitian disimpulkan bahwa penerapan model discovery learning berbasis pendekatan saintifik meningkatkan hasil belajar dan pembinaan karakter peserta didik.

Kata Kunci: Model discovery, Pendekatan saintifik, Hasil belajar, Penanaman karakter

Abstract: This study aims to improve learning outcomes and foster the character of students in grade IX SMP Negeri 3 Palopo which is taught by the application of Discovery learning model based on scientific approach to reproductive system material. This research is a class action research conducted in two cycles each cycle consists of four stages, namely planning, implementation, observation, and reflection. The research subjects were teachers and all students of grade IXA SMP Negeri 3 Palopo. Data collection using test techniques. Data analysis using descriptive techniques. The activities of learners consist of two categories, for the positive category has increased from cycle I cycle II cyclical to some aspects up to $100 \%$ and the negative category decreased by $0 \%$ for some aspects. Learning outcomes in the second cycle increased to 31 students $(100 \%)$ whose learning outcomes are complete. The results concluded that the application of discovery learning model based on scientific approach improves learning outcomes and character development of learners.

Keyword: Discovery model, Scientific approach, Learning outcomes, Character development. 


\section{PENDAHULUAN}

Kurikulum 2013 menekankan pada dimensi paedagogik modern dalam pembelajaran dengan menggunakan pendekatan scientific atau metode ilmiah. Pendekatan scientific (scientific approach) merupakan pengembangan sikap, keterampilan, dan pengetahuan peserta didik dalam pendekatan atau proses kerja yang memenuhi kriteria ilmiah. Seiring dengan Permendikbud No. 65 Tahun 2013 tentang Standar Proses Pendidikan Dasar dan Menengah telah mengisyaratkan tentang perlunya proses pembelajaran yang dipandu dengan kaidah-kaidah pendekatan saintifik/ilmiah. Proses pembelajaran scientific merupakan perpaduan antara proses pembelajaran yang semula terfokus pada eksplorasi, elaborasi, dan konfirmasi dilengkapi dengan mengamati, menanya, menalar, mencoba, dan mengkomunikasikan (Kemendikbud, 2013). Pendekatan saintifik terdiri dari empat model yaitu discovery learning, pembelajaran berbasisi Inquari learning, pembelajaran berbasis masalahpembelajaran berbasis masalah (problem-based learning/PBL) dan pembelajaran berbasis proyek (Project Based Learning / PJBL).

Temuan awal sebelum melakukan penelitian ini adalah bahwa di SMP Negeri 3 Palopo telah menerapkan kurikulum 2013, namun guru belum mampu menerapkan pendekatan saintifik, pembelajaran masih berpusat pada guru. Peserta didik hanya berpusat pada informasi yang diberikan serta menghafal materi yang didengar dan kurang memahami materi yang diajarkan sehingga proses pembelajaran belum kondusif, sehingga hasil belajar peserta didik masuk sangat rendah olehnya perlu pendekatan saintifik dalam proses pembelajaran IPA, penanaman karakter belum nampak dalam proses pembelajaran karena masih banyak peserta didik keluar masuk kelas dan mengganggu teman kelasnya. Salah satunya guru mata pelajaran IPA berinisiatif melakukan penerapan saintifik model discovery learning untuk melihat peningkatan hasil belajar dan penanaman karakter peserta didik kelas IX SMP 3 Palopo pada materi pewarisan sifat. Alasan memilih materi pewarisan sifat karena salah satu materi yang sulit dan menantang untuk dibahas, selain itu termasuk materi esensial sehingga sangat penting untuk dipahami. Berdasarkan hasil penelitian sebelumnya bahwa materi pewarisan sifat sulit dipahami karena terdapat miskonsepsi. (Destaria Sudirman, 2016).

Penerapan pendekatan saintifik dapat mengaktifkan seluruh peserta didik dalam proses pembelajaran serta mampu meningkatkan motivasinya yang besar dan memberikan dampak positif bagi penguasaan kompetensinya, peserta didik lebih inovatif dan kreatif. Penggunaan pendekatan pembelajaran saintifik berbasis discovery learning cocok diterapkan untuk meningkatkan hasil belajar dan penanaman karakter peserta didik. (Dina Dahliana et al. 2019). Discovery learning guru berperan sebagai pembimbing dengan memberikan kesempatan kepada peserta didik untuk belajar secara aktif, sebagaimana pendapat guru harus dapat membimbing dan mengarahkan kegiatan belajar peserta didik sesuai dengan tujuan (Sardiman, 2005:145). Sejalan dengan Fernanda, (2015) Bahwa discovery learning merupakan model pembelajaran yang dilandasi oleh teori konstruktivisme, dimana peserta didik aktif dalam proses pembelajaran untuk membangun pengetahuannya sendiri. Dengan aktifnya peserta didik dalam proses pembelajaran membuat pembelajaran menjadi lebih bermakna. Hal ini berdampak pada pemahaman yang diperoleh peserta didik menjadi lebih baik sehingga berpengaruh terhadap kemampuan kognitif atau hasil belajarnya. Pengetahuan peserta didik bertambah melalui proses penyelidikan yang mereka lakukan dalam rangka memecahkan suatu masalah sehingga mampu memperkuat konsep yang telah ada pada dirinya.

Pembelajaran melalui pendekatan saintifik adalah proses pembelajaran yang dirancang sedemikian rupa agar peserta didik secara aktif mengonstruksi konsep, hukum atau prinsip melalui tahapan-tahapan mengamati (untuk mengidentifikasi atau menemukan masalah), merumuskan masalah, mengajukan atau merumuskan hipotesis, mengumpulkan data dengan berbagai teknik, menganalisis data, menarik kesimpulan dan mengomunikasikan konsep, pendekatan saintifik signifikan adanya peningkatan pemahaman dan pemetaan penalaran peserta didik bidang 
tergantung gaya belajar hasil penelitian yang dikemukan oleh (Parmin et al., 2016; Abadi, Assaat \&amp; Pujiastuti 2017; Nagl, Obadovic \&amp; Segedinac 2012). Bahwa pendekatan saintifik melibatkan peserta didik secara langsung dan membantu mereka mengaitkan pembelajaran akademik dengan konteks kehidupan nyata yang mereka hadapi. Dengan mengaitkan pelajaran dengan kehidupan nyata yang diharapkan sehingga lebih kreatif, inovatif, dan mampu mengeluarkan ide-ide cemerlangnya dan memecahkan masalah yang dihadapi. adapun Langkahlangkah pembelajaran dengan pendekatan ilmiah umumnya diketahui oleh $5 \mathrm{~m}$. yaitu, amati, bertanya pada diri sendiri, mencoba, menganalisis, berkomunikasi (Utanto et al., 2017; Gunawan dkk., 2017).

Sejalah dengan hasil penelitian (Desi Ambarsari, 2016) menunjukkan bahwa keterampilan mengkomunikasikan dan prestasi belajar IPA meningkat setelah diberikan tindakan melalui penerapan pendekatan saintifik. Proses memaksimal penerapan pendekatan saintifik adalah guru memerluhkan modul untuk memahami pendekatan saintifik, perbedaan dari empat jenis model sehingga nantinya guru dapat memiliki model mana yang lebih tepat dengan materi yang akan diajarkan menurut sejalan dengan (Firman, et al. 2018) Modul berbasis pendekatan saintifik sangat penting digunakan dalam kegiatan pembelajaran terutama pada kurikulum 2013. Hal ini dikarenakan modul berbasis pendekatan saintifik memberikan keseimbangan, melatih serta memperkuat kompetensi peserta didik dalam hal sikap, pengetahuan dan kemampuan peserta didik secara utuh. Pendekatan saintifik dapat memberikan dan menanamkan nilai karakter peserta didik dlakukan melalui beberapa tahapan, yaitu: mulai dari mengamati, menanya, menalar, mencoba, dan mengkomunikasi. Penanaman nilai-nilai karakter dapat dilakukan dengan memberikan pengetahuan dan memberikan keyakinan tentang keberadaan Tuhan Yang Mahakuasa yang menciptakan makhluk hidup, menumbuhkan rasa syukur dan cara bersyukur atas kebesaran Allah (Agus Slamet, 2018).

Berdasarkan pemaparan tersebut guru IPA SMP Negeri 3 palopo berinisiatif melakukan penelitian dengan penerapan discovery learning untuk meningkatkan hasil belajar dan penanaman karakter peserta didik kelas IXA materi pewarisan sifat SMP Negeri 3 Palopo.

\section{METODE}

Penelitian ini merupakan jenis penelitian tindakan kelas (Classroom Action Research) dengan tahapan-tahapan pelaksanaan meliputi perencanaan, pelaksanaan tindakan, observasi, refleksi, perencanaan ulang. Variabel penelitian ini terdiri atas tiga yaitu Variabel input: Peserta didik kelas IXA SMP Negeri 3 Palopo 2. Variabel proses: Model pembelajaran Discovery Learning 3. Variabel output : aktivitas peserta didik sebagai indikator karakter peserta didik, peningkatan nilai hasil belajar. Untuk menghindari kesalahan penafsiran mengenai variabel penelitian maka berikut ini dijelaskan definisi operasional dari variabel output adalah: Hasil belajar IPA didefinisikan sebagai tingkat pengetahuan peserta didik kelas IXA SMP Negeri 3 Palopo tahun pelajaran 2019/2020 berdasarkan nilai tes hasil belajar IPA setelah pelaksanaan pembelajaran dengan penerapan model discovery pendekatan saintifik yang dilaksanakan setiap akhir siklus, penanaman karakter saat proses pembelajaran. Tahapan discovery learning sebagai berikut: 1. Stimulation (memberi stimulus) 2. Problem Statement (mengidentifikasi masalah), 3 menemukan permasalahan menanya, mencari informasi, dan merumuskan masalah. 4. Data Collecting (mengumpulkan data); mencari dan mengumpulkan data/informasi, melatih ketelitian, akurasi, dan kejujuran, mencari atau merumuskan berbagai alternatif pemecahan masalah, 5. Data Processing (mengolah data); mencoba dan mengeksplorasi pengetahuan konseptualnya, melatih keterampilan berfikir logis dan aplikatif. 6. Verification (memferifikasi); mengecek kebenaran atau keabsahan hasil pengolahan data, mencari sumber yang relevan baik dari buku atau media, mengasosiasikannya menjadi suatu kesimpulan. 7. Generalization (menyimpulkan); melatih pengetahuan metakognisi peserta didik. Discovery learning adalah penerapan atau pemberian penguatan-penguatan positif oleh guru 
kepada peserta didik yang memberikan respon dalam proses belajar mengajar IPA misalnya peserta didik yang menjawab pertanyaan, memberikan saran, menanggapi pendapat peserta didik lain dan sebagainya.

Penguatan itu diberikan dalam bentuk ucapan ataupun perbuatan. Subjek penelitian ini adalah siswa kelas IXASMP Negeri 3 Palopo yang berjumlah 31 orang yang diajar langsung oleh penulis. Penelitian ini dilaksanakan pada semester genap tahun ajaran 2019/2020. Rancangan penelitian tindakan kelas yang dilaksanakan terdiri atas dua siklus, yakni siklus pertama dan siklus kedua. Gambaran umum desain penelitian adalah secara umum yang dilakukan pada setiap siklus adalah: Perencanaan, pelaksanaan, pengamatan dan refleksi. Hasil refleksi menjadi acuan untuk melanjutkan siklus berikutnya dan menjadi perbaikan.

Teknik pengumpulan data yang akan dilakukan dalam penelitian ini adalah sebagai berikut : Data tentang aktifitas atau pembinaan karakter dalam kegiatan proses belajar mengajar diambil pada saat dilaksankan tindakan dengan menggunakan lembar observasi. Data mengenai tingkat pemahaman peserta didik diambil dari hasil belajar setelah pemberian tes hasil belajar pada tiap akhir siklus. Data mengenai aktifitas peserta didik dari hasil observasi akan dianalisis secara deskriptif, data tingkat pemahaman peserta didik akan dianalisis dengan menggunakan skor yang berdasarkan penilaian

Teknik analisis secara kuantitatif digunakan Nilai yang menjadi acuan Kriteria Ketuntasan Minimum (KKM) yang ditetapkan oleh sekolah) khususnya pada mata pelajaran IPA yang berlaku di kelas IXA SMP Negeri 3 Palopo yaitu 75,00. untuk nilai 75,00 ke atas dikategorikan tuntas dan untuk nilai dibawah 75,00 dikategorikan tidak tuntas.

\section{HASIL DAN PEMBAHASAN}

\section{Hasil}

\section{a. Aktivitas Peserta didik}

Aktivitas peserta didik selama proses pembelajaran dengan menerapkan discovery learning pendekatan saintifik pada Siklus I dapat dilihat pada tabel 1.

Tabel 1. Disribusi Hasil Observasi Aktivitas peserta didik pada Siklus I

\begin{tabular}{|c|c|c|c|c|c|}
\hline \multirow[b]{2}{*}{ No } & \multirow[b]{2}{*}{ Askpek Yang Diamati } & \multicolumn{2}{|c|}{ Pertemuan I } & \multicolumn{2}{|c|}{ Pertemuan II } \\
\hline & & $\begin{array}{c}\text { Jumlah } \\
\text { Peserta } \\
\text { Didik }\end{array}$ & $\%$ & $\begin{array}{c}\text { Jumlah } \\
\text { Peserta } \\
\text { Didik }\end{array}$ & $\%$ \\
\hline 1 & Kehadiran & 26 & 83,87 & 29 & 93,54 \\
\hline 2 & Menyimak Penjelasan Guru & 25 & 80,64 & 27 & 87,09 \\
\hline 3 & Memberikan Tanggapan & 25 & 80,64 & 27 & 87,09 \\
\hline 4 & Mengajukan Pertanyaan & 13 & 41,93 & 15 & 48,38 \\
\hline 5 & Menjawab Pertanyaan & 25 & 80,64 & 29 & 93,54 \\
\hline 6 & Mencatat Materi Pelajaran & 25 & 80,64 & 27 & 87,09 \\
\hline 7 & Membuat Kesimpulan & 15 & 48,38 & 20 & 64,51 \\
\hline 8 & $\begin{array}{l}\text { Perilaku yang Tidak Relevan dengan Proses } \\
\text { Pembelajaran }\end{array}$ & & & & \\
\hline & a. Berbicara yang tidak Perlu & 6 & 19,35 & 5 & 16,12 \\
\hline & b. Keluar Masuk Kelas & 5 & 16,12 & 5 & 16,12 \\
\hline & c. Main-main & 5 & 16,12 & 5 & 16,12 \\
\hline
\end{tabular}

Data Diolah (2019) 
Tabel 1 menunjukkan bahwa setelah dilaksanakan proses pembelajaran dengan menerapkan discovery learning pendekatan saintifik, aktivitas peserta didik pada siklus I mengalami peningkatan dari pertemuan I ke Pertemuan II terlihat dari data bahwa dari beberapa item yang menjadi fokus observasi persentase tertinggi aktifitas pada poin kehadiran peserta didik sebesar $83,87 \%$ pada pertemuan I menjadi $93,58 \%$ pada pertemuan ke II, menyimak penjelasan guru sebesar $80,64 \%$ pada pertemuan I menjadi 87,09\% pada pertemuan ke II demikian halnya dengan peserta didik yang mencatat meteri pelajaran dengan persentase sebesar $80,64 \%$ pada pertemuan I meningkat menjadi $87,09 \%$ pada pertemuan ke II, menjawab pertanyaan sebesar 80,64 pada pertemuan I meningkat menjadi 93,58 pada pertemuan ke II, membuat kesimpulan 48,38 pertemuan 1 meningkat menjadi 64,51 pada pertemuan I. Sedangkan persentase terendah pada poin mengajukan pertanyaan dengan persentase $41,93 \%$ pada pertemuan pertama meningkat menjadi $48,38 \%$ pada pertemuan ke II. Untuk perilaku yang tidak relevan dengan proses pembelajaran persentase tertinggi pada poin berbicara yang tidak perlu dan main-main sebesar $19,35 \%$ pada pertemuan I menurun menjadi 16,12\% pada pertemuan ke II. Keluar masuk kelas dan main-main sebesar $16,12 \%$ pada pertemuan I dan menurun menjadi $16,12 \%$ pertemuan ke II.

\section{b. Hasil Belajar Siswa}

Hasil belajar IPA siswa Kelas IXA SMP Negeri 3 Palopo setelah dilakukan proses pembelajaran dengan menerapkan discovery learning pendekatan saintifik pada siklus I dikategorikan menjadi empat (4) kategori sesuai ketuntasan hasil belajar minimal.

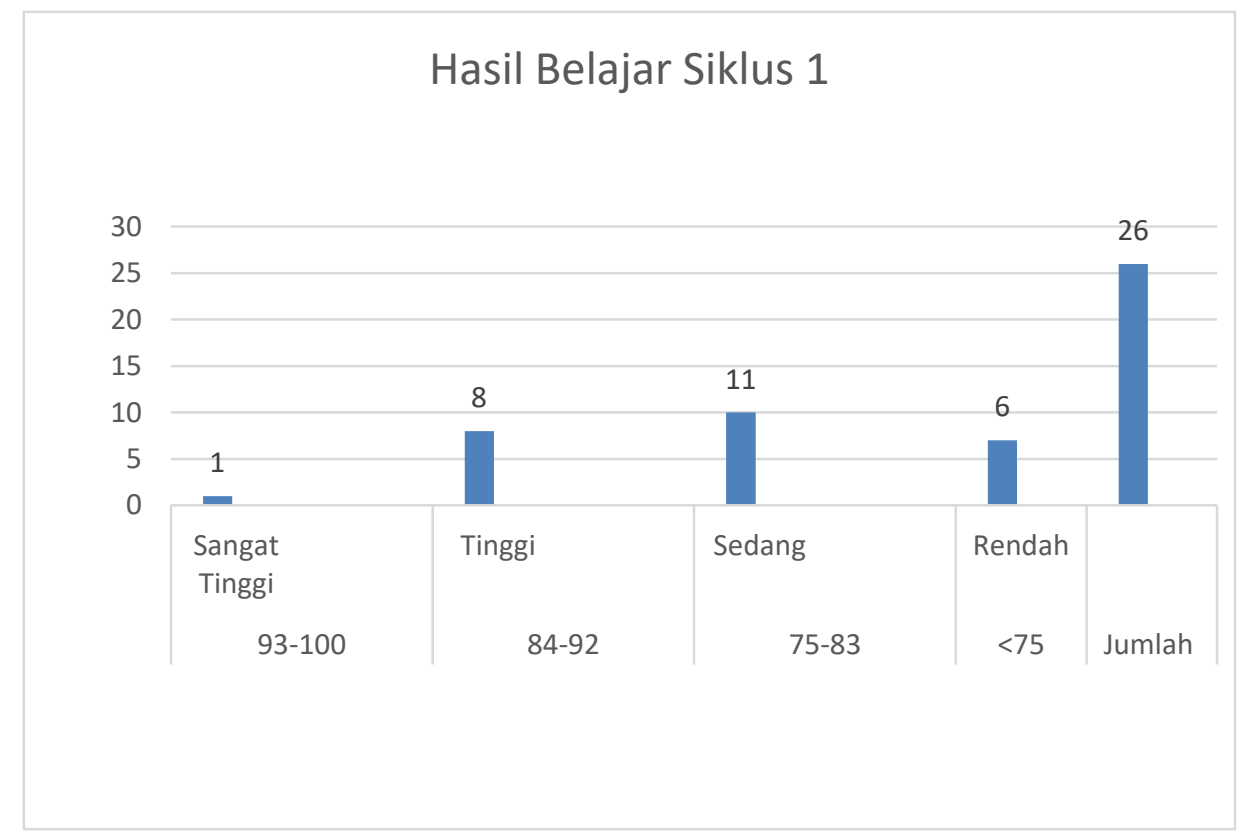

Gambar 1. Distribusi Hasil Belajar Peserta Didik pada Siklus I

Gambar 1 menunjukkan bahwa kategori hasil belajar IPA Peserta didik Kelas IXA SMP Negeri 3 Palopo pada Siklus I masih tergolong sedang dengan jumlah peserta didik terbanyak yakni 11 orang peserta didik $(35,48 \%)$ yang memiliki nilai dengan interval $75-83$, kategori tinggi sebanyak 8 orang peserta didik $(25,80 \%)$, kategori rendah sebanyak 7 orang peserta didik (19,35\%) yang memiliki nilai dengan interval $<75$ dengan kategori rendah dan kategori tinggi hanya satu orang saja (3,22\%) interval 93-100. Hasil belajar peserta didik tersebut kemudian dikelompokkan berdasarkan ketuntasan. 
Tabel 2. Distribusi Kategori Ketuntasan Belajar Minumum Peserta Didik Kelas IXA Pada Siklus I

\begin{tabular}{|c|c|c|c|}
\hline \multirow[b]{2}{*}{ Nilai Hasil Belajar } & \multirow[b]{2}{*}{ Kategori } & \multicolumn{2}{|c|}{ Siklus I } \\
\hline & & $\begin{array}{c}\text { Jumlah Peserta } \\
\text { Didik }\end{array}$ & Persentase \\
\hline$\geq 75,00$ & Tuntas & 21 & 67,74 \\
\hline$<75,00$ & Tidak Tuntas & 10 & 32,25 \\
\hline \multicolumn{2}{|c|}{ Jumlah } & 31 & 100 \\
\hline
\end{tabular}

Tabel 2 menunjukkan bahwa pada siklus I secara umum hasil belajar IPA peserta didik Kelas IXA SMP Negeri 3 Palopo belum mencapai ketuntasan terbukti dari hasil klasifikasi data masih terdapat 10 orang peserta didik (32,25\%) yang hasil belajarnya tidak tuntas dan terdapat 20 orang peserta didik $(67,74 \%)$ yang hasil belajarnya tuntas. Salah satu yang mempengaruhi ketidak tuntasan salah satu faktor kehadiran peserta didik. Penelitian ini dilanjutkan ke Siklus II dengan melakukan perbaikan atau tindak lanjut dari hal-hal yang masih kurang pada siklus I.

\section{Pelaksanaan Siklus II}

a. Aktivitas Peserta Didik

Aktivitas peserta didik selama proses pembelajaran dengan menerapkan discovery learning pendekatan saintifik pada Siklus II dapat dilihat pada tabel 3.

Tabel 3. Distribusi Hasil Observasi Aktivitas Peserta Didik pada Siklus II

\begin{tabular}{|c|c|c|c|c|c|c|}
\hline \multirow[b]{2}{*}{ No } & \multirow{2}{*}{\multicolumn{2}{|c|}{ Askpek Yang Diamati }} & \multicolumn{2}{|c|}{ Pertemuan I } & \multicolumn{2}{|c|}{ Pertemuan II } \\
\hline & & & $\begin{array}{l}\text { Jumlah } \\
\text { Siswa }\end{array}$ & $\%$ & $\begin{array}{l}\text { Jumlah } \\
\text { Siswa }\end{array}$ & $\%$ \\
\hline 1 & Kehadiran & & 31 & 100 & 31 & 100 \\
\hline 2 & Menyimak Penjelasan Guru & & 31 & 100 & 31 & 100 \\
\hline 3 & Memberikan Tanggapan & & 28 & 93,54 & 30 & 96,77 \\
\hline 4 & Mengajukan Pertanyaan & & 28 & 93,54 & 30 & 96,77 \\
\hline 5 & Menjawab Pertanyaan & & 30 & 96,77 & 31 & 100 \\
\hline 6 & Mencatat Materi Pelajaran & & 31 & 100 & 31 & 100 \\
\hline 7 & Membuat Kesimpulan & & 30 & 93,54 & 31 & 100 \\
\hline \multirow[t]{4}{*}{8} & $\begin{array}{l}\text { Perilaku yang Tidak Relevan dengan } \\
\text { Pembelajaran }\end{array}$ & Proses & & & & \\
\hline & a. Berbicara yang tidak Perlu & & 3 & 9,67 & 2 & 6,45 \\
\hline & b. Keluar Masuk Kelas & & 1 & 3,22 & 0 & 0 \\
\hline & c. Main-main & & 1 & 3,22 & 0 & 0 \\
\hline
\end{tabular}

Tabel 3 menunjukkan bahwa setelah dilaksanakan proses pembelajaran dengan penerapan model discovery learning pendekatan saintifik pada tahapan Siklus II dengan tahapan pembelajaran yang telah ditetapkan seperti pada siklus I tetapi telah dilakukan tindak lanjut terhadap hal-hal yang masih kurang pada siklus I, hasil observasi pada siklus II mengalami peningkatan keaktifan peserta didik dimana terlihat persentase tertinggi dari segi aktivitas peserta didik pada poin kehadiran, menyimak penjelasan guru dan mencatat materi pelajaran sebesar $100 \%$, pada pertemuan I dan 
pertemuan ke II, menjawab pertanyaan dan mengajukan kesimpulan sebesar 93,54\% pada siklus pertemuan I meningkat menjadi $100 \%$ pada pertemuan II, Persentase rendah pada poin memberi tanggapan dan mengajukan pertanyaan sebesar 93,54 pada pertemuan I dan meningkat menjadi $96,77 \%$ pada pertemuan II. Mengenai perilaku yang tidak relevan dengan proses pembelajaran persentase tertinggi pada poin berbicara yang tidak perlu dengan persentase $9,67 \%$ pada pertemuan I menurun menjadi 6,45\% pada pertemuan II, keluar masuk kelas dan main-main pada siklus I sebesar 3,22\% dan menurun menjadi $0 \%$ pada pertemuan II.

\section{b. Hasil Belajar Siswa}

Hasil belajar IPA siswa IX SMP Negeri 3 Palopo mengalami peningkatan dari siklus I ke siklus II. Hasil belajar biologi siswa setelah dilakukan proses pembelajaran dengan penerapan model discovery learning pendekatan saintifik pada siklus II dapat dikategorikan menjadi menjadi empat (4) kategori sesuai ketuntasan hasil belajar minimal.

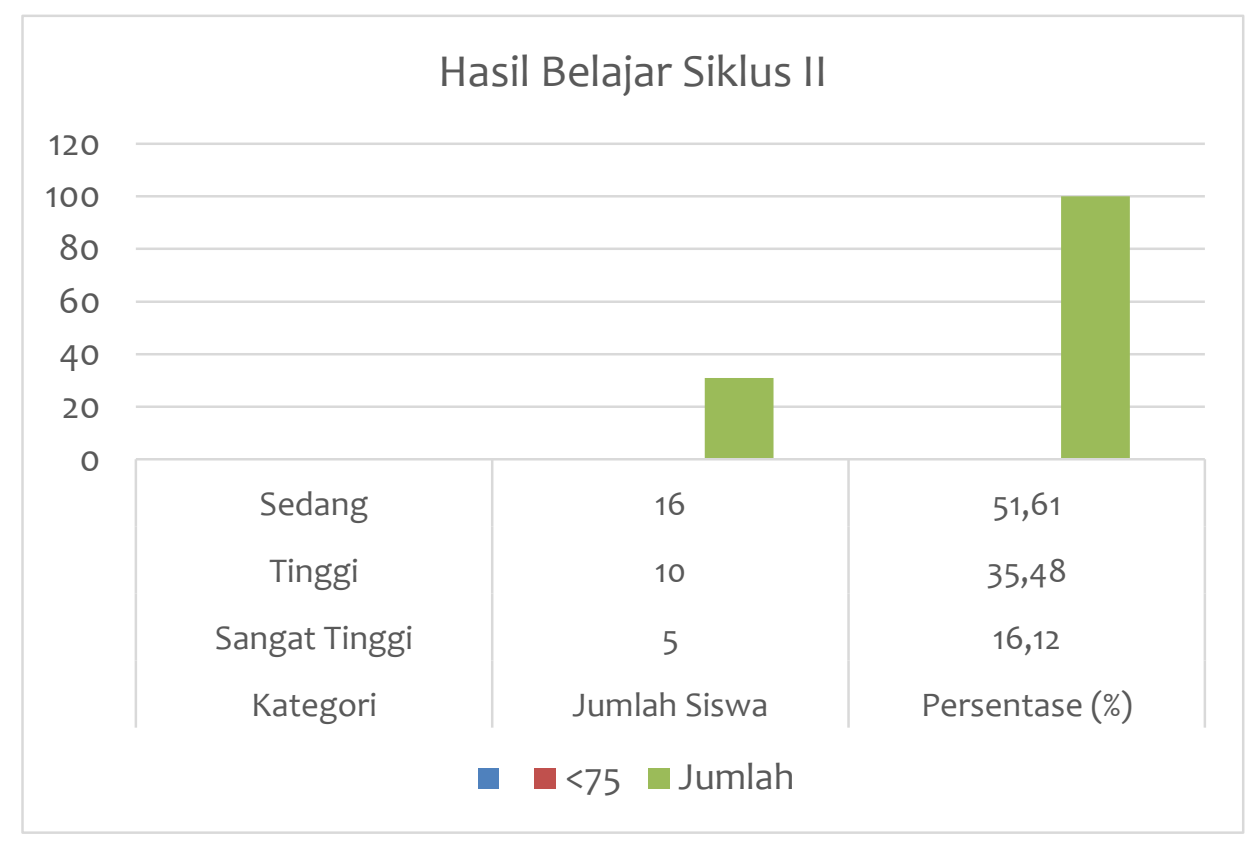

Gambar 2. Distribusi Hasil Belajar Peserta Didik Pada Siklus II

Gambar 2 menunjukkan bahwa kategori hasil belajar IPA peserta didik Kelas IX A SMP Negeri 3 Palopo pada Siklus II mengalami peningkatan dari siklus I dengan jumlah siswa terbanyak 16 orang peserta didik (51,61\%) yang memiliki nilai dengan interval nilai 75-83 dengan kategori sedang, 10 orang peserta didik $(35,48)$ yang nilainya berada pada interval 84-92 pada kategori tinggi dan 5 orang siswa $(16,12 \%)$ yang hasil belajarnya berada pada interval 93-100 pada kategori sangat tinggi, tidak ada lagi kategori rendah.

Hasil belajar tersebut kemudian dikelompokkan berdasarkan kriteria ketuntasan minimum IPA (KKM IPA). Mengenai kategori ketuntasan berdasarkan kriteria ketuntasan belajar minimum biologi peaert didik pada siklus II dapat dilihat pada tabel 4. 
Tabel 4. Distribusi Kategori Ketuntasan Belajar Minimum Peserta Didik Pada Siklus II

\begin{tabular}{|c|c|c|c|}
\hline \multirow[b]{2}{*}{ Nilai Hasil Belajar } & \multirow[b]{2}{*}{ Kategori } & \multicolumn{2}{|c|}{ Siklus II } \\
\hline & & $\begin{array}{c}\text { Jumlah Peserta } \\
\text { Didik }\end{array}$ & Persentase \\
\hline$\geq 75,00$ & Tuntas & 31 & 100 \\
\hline$<75,00$ & Tidak Tuntas & 0 & 0 \\
\hline \multicolumn{2}{|c|}{ Jumlah } & 31 & 100 \\
\hline
\end{tabular}

Tabel 4 menunjukkan bahwa terjadi peningkatan ketuntasan belajar IPA dari siklus I ke siklus II. Pada Siklus II, terjadi peningkatan menjadi 31 orang peserta didik (100\%) yang hasil belajarnya tuntas. Dengan demikian penelitian berakhir pada siklus II karena ketuntasan belajar peserta didik telah mencapai ketuntasan klasikal hasil belajar IPA.

\section{Pembahasan}

Berdasarkan analisis aktivitas peserta didik pada siklus I menunjukkan bahkan menunjukkan bahwa setelah dilaksanakan proses pembelajaran dengan menerapkan discovery learning pendekatan saintifik, aktivitas peserta didik pada siklus I mengalami peningkatan dari pertemuan I ke Pertemuan II terlihat dari data bahwa dari beberapa item aspek positif yaitu kehadiran peserta didik, menyimak penjelasan guru, memberikan tanggapan, mengajukan pertanyaan, menjawab pertanyaan, mencatat materi pelajaran dam membuat kesimpulan semua mengalami peningkatan sedangkan aspek negatif yaitu keluar masuk kelas, berbicara yang tidak perluh, dan main-main. Namun sikap yang terlihat pada siklus I walaupun sudah mengalami peningkatan kea rah yang lebih baik tetapi masih perlu diperbaiki sehingga dilanjutkan kesiklus II. Adapun analisis aktifatas peserta didik pada siklus II mengalami peningkatan yang signifikan. Dapat dilihat pada tabel 1 dan tabel 3 berdasarkan tabel hasil analisis aktifitas peserta didik bahwa penerapan model discovery learning pendekatan saintifik menitipberatkan pada pembentukan atau penanaman karakter peserta didik, sikap positif peserta didik terbentuk dalam proses pembelajaran (Driver, Newton, \& Osborne, 2000; VanHoorn, Nourot, Scales, \& Alward, 2014). Pendekatan saintifik dapat memberikan dan menanamkan nilai karakter peserta didik dilakukan melalui beberapa tahapan, yaitu: mulai dari mengamati, menanya, menalar, mencoba, dan mengkomunikasi.

Penelitian yang dilakukan dengan penerapan discovery learning dimulai dari tahapan stimulation (memberi stimulus). Pada kegiatan ini guru memberikan stimulant berupa bacaan materi sistem reproduksi, peserta didik mendapat pengalaman belajar mengamati pengetahuan konseptual melalui kegiatan membaca. Problem Statement (mengidentifikasi masalah). Dari tahapan tersebut, peserta didik menemukan permasalahan apa saja yang dihadapi atau terkait dengan system reproduksi sehingga pada kegiatan ini peserta didik diberikan pengalaman untuk menanya, mencari informasi, dan merumuskan masalah. Data Collecting (mengumpulkan data). Pada tahapan ini peserta didik diberikan pengalaman mencari dan mengumpulkan data/informasi yang dapat digunakan untuk menemukan solusi pemecahan masalah yang dihadapi. Kegiatan ini juga akan melatih ketelitian, akurasi, dan kejujuran, serta membiasakan peserta didik untuk mencari atau merumuskan berbagai alternatif pemecahan masalah, jika satu alternatif mengalami kegagalan. Data Processing (mengolah data). Kegiatan mengolah data akan melatih peserta didik untuk mencoba dan mengeksplorasi kemampuan pengetahuan konseptualnya untuk diaplikasikan pada kehidupan nyata, sehingga kegiatan ini juga akan melatih keterampilan berfikir logis dan aplikatif. Verification (memferifikasi). Tahapan ini mengarahkan peserta didik untuk mengecek kebenaran atau keabsahan hasil pengolahan data, melalui berbagai kegiatan, antara lain bertanya kepada teman, berdiskusi dan mencari sumber yang relevan baik dari buku serta 
mengasosiasikannya sehingga menjadi suatu kesimpulan. Generalization (menyimpulkan). Pada kegiatan ini peserta didik digiring untuk menggeneralisasikan hasil simpulannya pada suatu kejadian atau permasalahan terkait sistem reproduksi, sehingga dapat melatih pengetahuan metakognisi peserta didik. Dengan penerapan sintaks tersebut sehingga dapat dilihat bahkan hasil belajar peserta didik pada siklus I dan siklus II mengalami peningkatan drastis.

Adapun hasil belajar pada siklus I dapat dilihat pada tabel 2 menunjukkan bahwa hasil belajar pada siklus 1 persentase ketuntasan 67,74 dan yang belum tuntas 32,25. Berdasarkan persentase ketuntasan tersebut belum mengalami ketuntasan 90\% sehingga dasar untuk melanjutkan siklus II, siklus II penyempurnaan perlakuan refleksi dari siklus I, adapun hasil belajar pada siklus II dapat dilihat pada tabel 4 persentase ketuntasan hasil belajar mencapai hasil 100\% ini menunjukkan bahwa penerapan discovery learning pada materi pewarisan sifat mengalami peningkatan secara signifikan. Hal ini membuktikan bahwa penerapan discovery learning pendekatan saintifik dapat meningkatkan hasil belajar karena semua peserta didik aktif, serius, dan antusias dalam proses pembelajaran dan guru pun merasa puas dengan kegiatan pembelajaran. Kepuasan guru karena aktivitas peserta didik dalam aspek positif mengalami peningkatan dan aspek negative mengalami penurutan dan berdampak ke hasil belajar dari siklus I ke siklus II. Guru sangat memerlukan modul terkait dengan pemahaman untuk penerapan pendekatan saintifik hal ini sejalan dengan (Firman, et al. 2018) Modul berbasis pendekatan saintifik sangat penting digunakan dalam kegiatan pembelajaran terutama pada kurikulum 2013. Hal ini dikarenakan modul berbasis pendekatan saintifik memberikan keseimbangan, melatih serta memperkuat kompetensi peserta didik dalam hal sikap, pengetahuan dan kemampuan peserta didik secara utuh. Hal ini dikarenakan modul berbasis pendekatan saintifik memberikan keseimbangan, melatih serta memperkuat kompetensi peserta didik dalam hal sikap, pengetahuan dan kemampuan peserta didik secara utuh. Modul merupakan seperangkat bahan ajar yang disajikan secara sistematis dengan tujuan agar peserta didik dapat belajar secara mandiri tanpa atau dengan bimbingan seorang guru. Sedangkan, pendekatan saintifik merupakan pendekatan yang dilakukan secara ilmiah sesuai dengan kurikulum 2013 dengan memuat $5 \mathrm{M}$ seperti, mengamati, menanya, mencoba, menalar atau mengasosiasikan dan mengkomunikasikan dengan tujuan melibatkan peserta didik dalam kegiatan pengamatan yang dibutuhkan untuk perumusan hipotesis atau mengumpulkan data Abdullah Sani, (2015).

Penerapan pembelajaran discovery learning, menggambarkan kegaiatan pembelajaran student center (kegiatan pembelajaran berpusat pada peserta didik, guru hanya menyampaikan materi penting dan singkat. Hal ini dikarenakan pembelajaran discovery learning menekankan pada kemampuan dan aktivitas peserta didik dalam kegiatan pembelajaran. Pengembangan materi diwujudkan guru dalam bentuk tugas kelompok yang diberikan sehingga dapat memberikan kesempatan kepada peserta didik untuk mendiskusikan dengan kelompoknya. Tiap peserta didik memiliki pendapat dan cara yang berbeda dalam menyelesaikan persoalan yang diberikan. Model pembelajaran discovery learning wajib memperhatikan karakteristik peserta didik, karena merupakan kelompok yang heterogen. Model pembelajaran discovery learning melatih peserta didik fokus terhadap pokok materi yang dibahas. Penerapan model pembelajaran discovery learning pendekatan saintifik pada materi pewarisan sifat di kelas IX A SMP Negeri 3 Palopo dapat meningkatkan hasil belajar dan penanaman karakter peserta didik peserta didik sehingga pembelajaran lebih bermakna dan mudah dipahami. Penerapan model pembelajaran ini membuat peserta didik menjadi lebih aktif, termotivasi, dalam mengumpulkan data untuk memahami konsep pewarisan sifat. Kegiatan berkelompok mengasah kemampuan peserta didik berpendapat sehingga nantinya dapat digunakan dalam kehidupan sehari-hari untuk mengambil langka yang tepat.

Sejalan dengan Pembelajaran melalui pendekatan saintifik adalah proses pembelajaran yang dirancang sedemikian rupa agar peserta didik secara aktif mengonstruksi konsep, hukum atau prinsip melalui tahapan-tahapan mengamati (untuk mengidentifikasi atau menemukan masalah), merumuskan masalah, mengajukan atau merumuskan hipotesis, mengumpulkan data dengan 
berbagai teknik, menganalisis data, menarik kesimpulan dan mengomunikasikan konsep, pendekatan saintifik signifikan adanya peningkatan pemahaman dan pemetaan penalaran peserta didik bidang tergantung gaya belajar hasil penelitian yang dikemukan oleh (Parmin et al., 2016; Abadi, Assaat \&amp; Pujiastuti 2017; Nagl, Obadovic \&amp; Segedinac 2012). Bahwa pendekatan saintifik melibatkan peserta didik secara langsung dan membantu mereka mengaitkan pembelajaran akademik dengan konteks kehidupan nyata yang mereka hadapi. Dengan mengaitkan pelajaran dengan kehidupan nyata yang diharapkan sehingga lebih kreatif, inovatif, dan mampu mengeluarkan ide-ide cemerlangnya dan memecahkan masalah yang dihadapi. Adapun langkah-langkah pembelajaran dengan pendekatan ilmiah umumnya diketahui oleh $5 \mathrm{~m}$. yaitu, amati, bertanya pada diri sendiri, mencoba, menganalisis, berkomunikasi (Utanto et al., 2017; Gunawan dkk., 2017).

Hal ini dikemukakan juga (Dina Dahliana et al. 2019) bahwa penggunaan pendekatan pembelajaran saintifik berbasis discovery learning cocok diterapkan untuk meningkatkan hasil belajar dan penanaman karakter peserta didik. (Menurut Nur alamsyah 2016) bahwa pendekatan saintifik dapat meningkatkan kreatifitas dan hasil belajar siswa.

\section{KESIMPULAN}

Berdasarkan hasil Analisa data dan pembahasan maka dapat disimpulkan bahwa penerapan discovery learning dapat meningkatkan hasil belajar dan penanaman karakrer peserta didik materi sistem reproduksi pada kelas IXA SMP Negeri 3 Palopo.

\section{DAFTAR PUSTAKA}

Abadi, M. K., Pujiastuti H., Assaat L. D. (2017). Development of Teaching Materials Based Interactive Scientific Approach towards the Concept of Social Arithmetic For Junior High School Student. International Conference on Mathematics and Science Education: Journal of Physics: Conf. Series 812

Sani, A. R. (2015). Pembelajaran Saintifik untuk Implementasi Kurikulum 2013. Jakarta: Bumi Aksara.

Slamet, A. (2018). Scientific Approach in Imparting Islamic Values in Early Childhood: A case study in Raudatul Aisyiyah Athfal Baubau L-TA'LIM JOURNAL, 25 (1), 2018, (71-76) (Print ISSN 14107546 Online ISSN 2355-7893) Available online at http://journal.tarbiyahiainib.ac.id/index.php/attalim. This work is licensed under (CC-BY-SA).

Ambarsari, D. (2016). Implementation of scientific Aproach To Improve Communicating and science Learning Achievement on 4Th Grade Students. Jurnal Pendidikan Guru Sekolah Dasar Edisi 12 Tahun ke-5 PGSD Universitas Pendidikan Ganesha Jurusan PGSD Vol: 4 No: 1 Tahun: 2016.

Sudirman, D. (2016). Identifikasi Miskonsepsi Siswa Pada Materi Pewarisan Sifat Di Kelas IX SMP Negeri 36 Batam. https://www.journal.unrika.ac.id/index.php (Diakses 10 Maret 2021). Online.

Dahliana, D., Setiawati, N.S., \& Taufina. (2019). Pendekatan Saintifik Dalam Meningkatkan Hasil Belajar Pembelajaran IPA Di Kelas IV Siswa Sekolah Dasar. Jurnal Pesona Dasar Universitas Syiah Kuala Vol.7 No.2, Oktober 2019, hal. 10 - 17 ISSN: 2337-9227. Online Jurnal.unsyiah.ac.id/PEAR/article/view/14754. (Diakses 17 januari 2021 Diakses 17 januari 2021).

Driver, Newton, \& Osborne, 2000; VanHoorn, Nourot, Scales, \& Alward, 2014). Classrooms. Science Education, 84(3), 287-312.

Firman, B., \& Murtini, W. (2018). The Effectiveness of The Scientific Approach to Improve Student Learning Outcomes. International Journal of Active Learning, (Online), Vol. 3, No. 2, (http://journal.unnes.ac.id, Diakses 17 januari 2021).

Kemendikbud. (2013). Permendikbud no.81 A 2013 tentang implementasi kurikulum.Jakarta: kementerian Pendidikan dan Kebudayaan. 
Khaeruddin, K., Ibrahim, M., \& Supardi, I. Z. A. (2011). Mengembangkan Karakter Tanggung Jawab dan Kemampuan Akademik Siswa melalui Pendekatan Pembelajaran Penemuan (Discovery Learning). JPPS: Jurnal Penelitian Pendidikan Sains, 1(1) (Online diakses 10 Maret 2021).

Mastuang., Erliana, E., Misbah., \& Miriam, S. (2017). Penerapkan model discovery learning untuk meningkatkan karakter tanggung jawab dan kemampuan kognitif siswa. Pendidikan Fisika, FKP, Universitas Lambung Mangkura. Jurnal Pendidikan Informatika dan Sains, Vol.6, No. 2, Desember 2017. Online diakses 10 Maret 2021.

Nagl, G. M, Obadovic, Z. D, Segedinac, M. (2012). Effective Teaching of Physics and Scientific Method". TEM Journal 1(2).

Nur alamsyah. (2016). Penerapan pendekatan saintifik untuk meningkatkan kreativitas dan hasil belajar siswa dalam mata pelajaran IPA. Jurnal Pendidikan Volume 1 Nomor 1 Tahun 2016 Halaman: 81 - 88 ISSN: 2527-6891 Online (Diakses 18 Januari 2021).

Parmin, Sajidan, Ashadi, Sutikno, \& Maretta, Y. A. (2016). Preparing Prospective Teachers in Integrating Science and Local Wisdom through Practicing Open Inquiry. Journal of Turkish Science Education, 13(2), 3-14.

Said, M.I., Sutadji, E \& Sugandi, M. (2016). He Scientific Approach-Based Cooperative Learning Tool For Vocational Students Vocation Program Of Autotronic (Automotive Electronic) Engineering. Journal of Research \& Method in Education. 6 (3) 67-73

Utanto, Y., Widhanarto, G. P., \& Maretta, Y. A. (2017). A web-based portfolio model as the students' final assignment: Dealing with the development of higher education trend. Dipersentasekan di International Conference AIP Publishing. (Vol. 1818, No. 1, p. 020063).

\author{
Hj Sitti Hadijah \\ Guru Mata Pelajaran IPA di SMP Negeri 3 Palopo, dapat dihubungi melalui email: \\ Kasmi20ogindi@gmail.com.
}

